Florida International University FIU Digital Commons

$1-13-2012$

\title{
An Investigation of the Relationships between Selected Characteristics and Leadership Outcomes of Athletic Training Education Program Directors
}

Michelle L. Odai

Florida International University, odaim@fiu.edu

DOI: $10.25148 /$ etd.FI12050201

Follow this and additional works at: https://digitalcommons.fiu.edu/etd

\section{Recommended Citation}

Odai, Michelle L., "An Investigation of the Relationships between Selected Characteristics and Leadership Outcomes of Athletic Training Education Program Directors" (2012). FIU Electronic Theses and Dissertations. 594.

https://digitalcommons.fiu.edu/etd/594 


\section{FLORIDA INTERNATIONAL UNIVERSITY \\ Miami, Florida}

AN INVESTIGATION OF THE RELATIONSHIPS BETWEEN SELECTED

CHARACTERISTICS AND LEADERSHIP OUTCOMES OF ATHLETIC TRAINING

EDUCATION PROGRAM DIRECTORS

A dissertation submitted in partial fulfillment of the

requirements for the degree of

DOCTOR OF PHILOSOPHY

in

CURRICULUM AND INSTRUCTION

by

Michelle L. Odai 
To: Dean Delia C. Garcia

College of Education

This dissertation, written by Michelle L. Odai, and entitled An Investigation of the Relationships Between Selected Characteristics and Leadership Outcomes of Athletic Training Education Program Directors, having been approved in respect to style and intellectual content, is referred to you for judgment.

We have read this dissertation and recommend that it be approved.

Charmaine DeFrancesco

\begin{tabular}{c}
\hline Richard Lopez \\
\hline Mohammed Farouk, Co-Major Professor \\
Glenda Musoba, Co-Major Professor
\end{tabular}

Date of Defense: January 13, 2012

The dissertation of Michelle L. Odai is approved.

Dean Delia C. Garcia College of Education

Dean Lakshmi N. Reddi University Graduate School

Florida International University, 2012 
(C) Copyright 2012 by Michelle L. Odai

All rights reserved. 


\section{DEDICATION}

I dedicate this dissertation to my family and especially my mother. Without their love and support, this would not have been possible. 


\section{ACKNOWLEDGMENTS}

I wish to thank the members of my committee for their guidance throughout this process. 
ABSTRACT OF THE DISSERTATION

AN INVESTIGATION OF THE RELATIONSHIPS BETWEEN SELECTED

CHARACTERISTICS AND LEADERSHIP OUTCOMES OF ATHLETIC TRAINING

EDUCATION PROGRAM DIRECTORS

by

Michelle L. Odai

Florida International University, 2012

Miami, Florida

Professor Mohammed Farouk, Co-Major Professor

Professor Glenda Musoba, Co-Major Professor

There is currently no evidence describing what characteristics make an Athletic Training Program Director (PD) an effective leader. An influx of accredited programs resulted in a rapid increase in the demand for PDs, yet training and preparation for these positions has failed to evolve. Although Certified Athletic Trainers (ATs) are trained in specific content areas, they may not always be prepared for the administrative and leadership responsibilities associated with the role of PD (Leone, 2008). This dissertation examined the relationships between selected characteristics and leadership outcomes of Athletic Training Program Directors.

Each PD participants ( $n=27)$ completed a demographic questionnaire to obtain the leader's academic preparation, accreditation experience and leadership training history. Each participant also completed the Multifactor Leadership Questionnaire (MLQ) to obtain leadership styles, behaviors, and outcomes. Overall, the PDs reported utilizing transformational leadership most often and passive avoidant leadership least often. There 
was no significant difference between PDs with master's and doctorate degrees on overall leadership outcome. However, participants with a doctorate degree scored significantly different on the effectiveness component of the leadership outcome compared with participants with a master's degree. Those participants who have completed academic coursework on leadership scored significantly different on the leadership outcome compared to those who have not completed academic coursework on leadership.

Findings from this study indicate that changes to the current requirements for the role of PD may be warranted. Consideration should be given to increasing the minimum degree requirement and requiring academic coursework on leadership. Future research may be useful in determining specific degree guidelines and types and amounts of leadership training that would be beneficial to Athletic Training PDs. 


\section{TABLE OF CONTENTS}

CHAPTER

PAGE

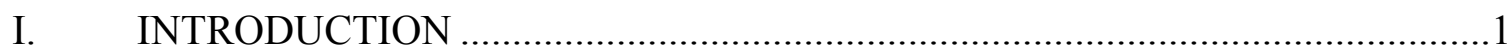

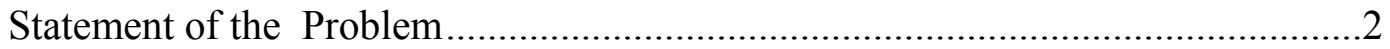

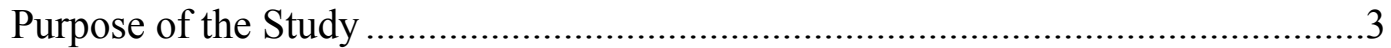

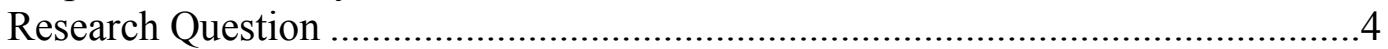

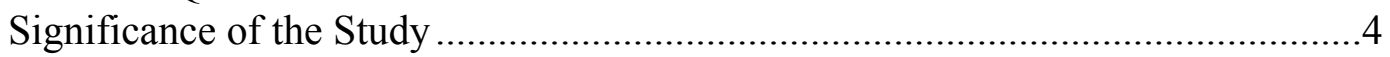

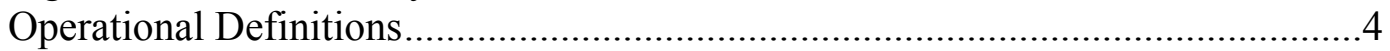

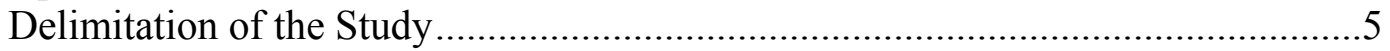

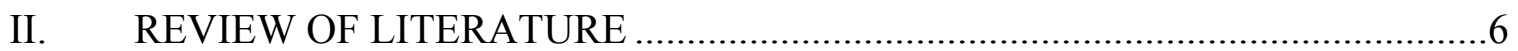

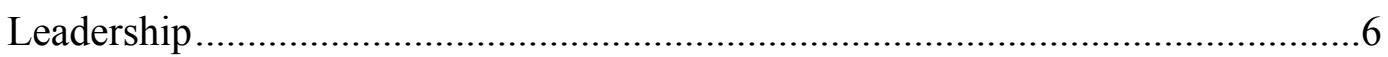

Bass' Full-Range of Leadership Model .............................................................

Leadership in Higher Education ...............................................................15

Athletic Training Education............................................................................

Related Research in Higher Education ........................................................22

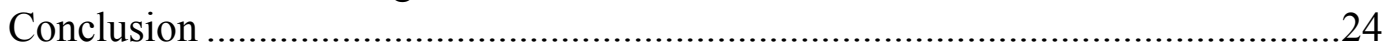

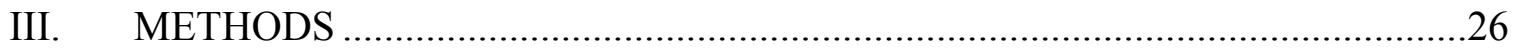

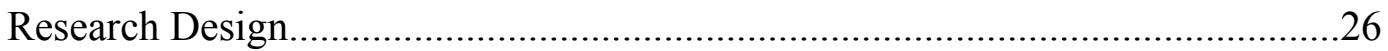

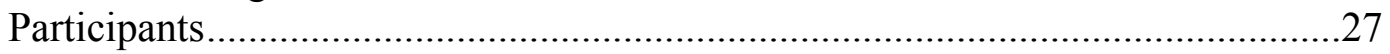

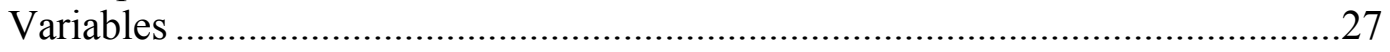

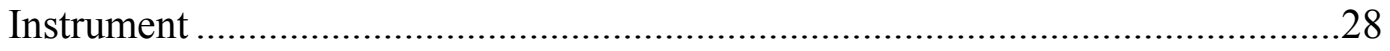

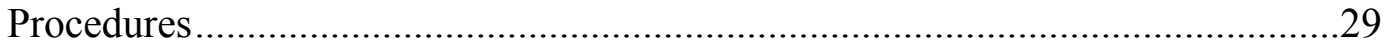

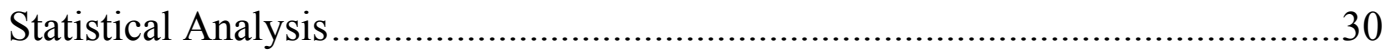

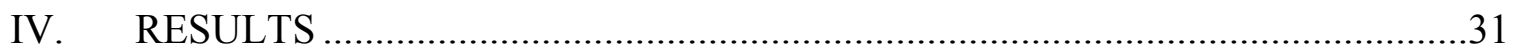

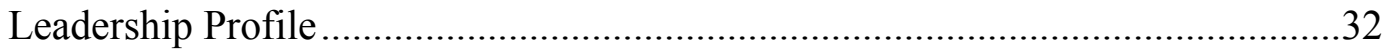

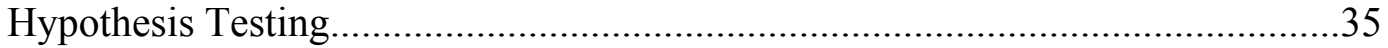

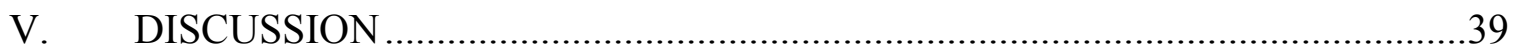

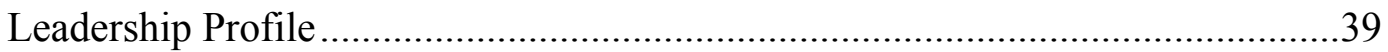

Academic Preparation..................................................................................4

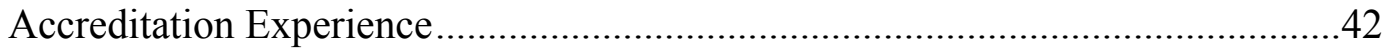

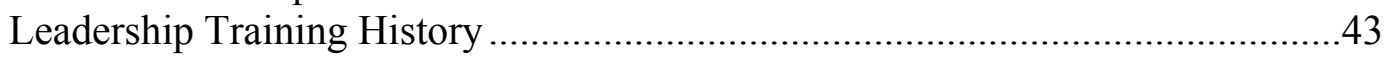

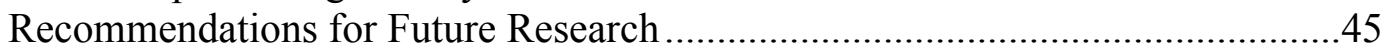

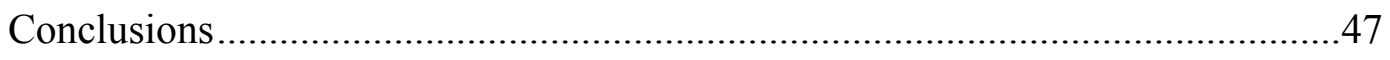

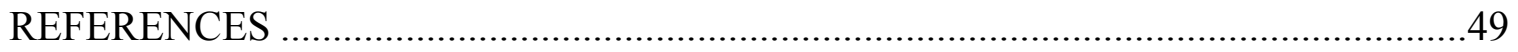

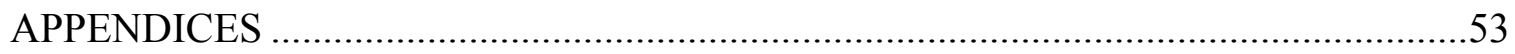

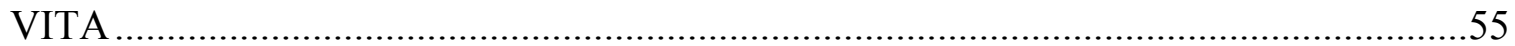




\section{LIST OF TABLES}

TABLE

PAGE

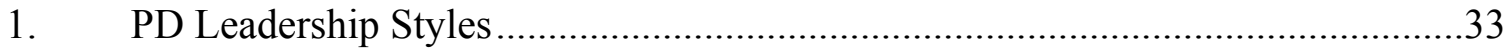

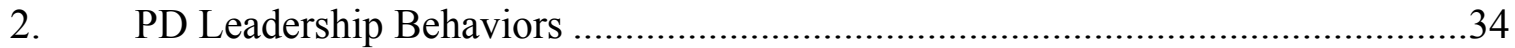

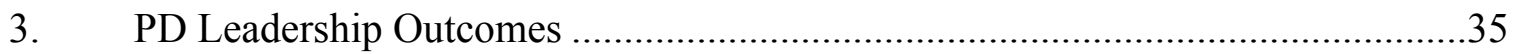

4. Mann-Whitney U Test for Masters/Doctorate Degree........................................36

5. Spearman's Rho Correlation for Accreditation Experience .................................36

6. Mann-Whitney U Test for Academic Coursework .............................................37

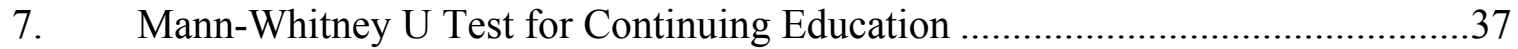

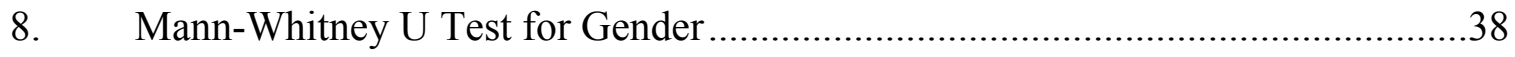




\section{CHAPTER ONE}

\section{INTRODUCTION}

Certified Athletic Trainers (ATs) are allied healthcare professionals whose scope of practice includes meeting the healthcare needs of individuals involved in physical activity (National Athletic Trainers' Association, 2006). An aspiring AT must graduate from an entry-level Commission on Accreditation of Athletic Training Education (CAATE) accredited program to be eligible for professional credentialing. It is the responsibility of an institution to demonstrate compliance with the Standards for the Accreditation of Entry Level Educational Programs for the Athletic Trainer to obtain and maintain recognition as a CAATE-accredited Program (CAATE, 2006). At the programmatic level, the Athletic Training Education Program Director (PD) is the individual responsible for the organization and administration of all aspects of the educational program as mandated by the CAATE and serves as a leader to the faculty, staff, and students within the program.

The profession of Athletic Training has undergone educational reform and growth in the past several years and the characteristics, roles, and responsibilities of PDs have commensurately evolved. Athletic Training Education Programs are attempting to align with other allied health educational programs at colleges and universities; however, the qualifications required to serve as a PD fall short of those required in other health care professions (Judd \& Perkins, 2004). Athletic Training PDs must possess a bachelor's degree and have 5 years of experience as a certified Athletic Trainer in any work setting. PDs are not required to have any graduate coursework, previous accreditation experience or leadership training. The current qualifications required to hold the title of PD fail to 
reflect the importance of experience or effective leadership in this position. The researcher feels that an examination and possibly modification of the current qualifications is necessary to ensure that Athletic Training remains a legitimate health care profession.

Leadership is a process whereby an individual influences a group of individuals to achieve a common goal (Northouse, 2010). Effective program leadership is crucial for success in an evolving academic environment (Bordage, Foley, \& Goldyn, 2000). An effective leader is one who attains results through specific actions while maintaining consistency with organizational goals. These specific actions raise associates' desire to succeed and may include encouraging personal and organizational growth and development, providing the resources necessary to be successful, communicating efficiently and effectively with others, and creating a sense of community within an organization. Although early literature described a one-dimensional focus, Bass (1985a) developed a $360^{\circ}$ view of leadership styles, behaviors, and outcomes measured by the Multifactor Leadership Questionnaire (MLQ). His Full-Range of Leadership model describes a continuum of leadership across three styles: transformational, transactional, and passive avoidant (Avolio \& Bass, 2004; Bass, 1985a, 1985b). The MLQ has $360^{\circ}$ evaluative capability that allows an investigator to assess leadership styles, behaviors, and outcomes through various viewpoints.

\section{Statement of the Problem}

As of 2009, there were 346 CAATE accredited undergraduate Athletic Training Education Programs in the United States. There were an additional 20 CAATE accredited entry-level master's degree programs and several more programs applying for 
accreditation. At the end of 1997, there were only 82 accredited programs, an increase of over $300 \%$ (CAATE, 2007). The influx of accredited programs resulted in a rapid increase in the demand for PDs, yet training and preparation for these positions has failed to evolve. Although Certified Athletic Trainers are trained in specific content areas, they may not always be prepared for the administrative and leadership responsibilities associated with the role of PD (Leone, Judd, \& Colandreo, 2008). Those in PD positions must provide effective leadership to solidify a legitimate place for ATs as healthcare providers and educators in highly competitive allied health care and higher education environments (Peer \& Rakich, 2000). PDs cannot be content or reactive leaders. They must be effective and proactive in preparing programs, colleagues, and students for the future of the profession of Athletic Training. PDs must possess effective leadership skills that inspire and facilitate faculty and students to perform at their highest levels (Zuest, 2003).There is currently no evidence describing what characteristics make an Athletic Training PD an effective leader. Administering the MLQ to Athletic Training Education PDs offered insight into the leadership styles, behaviors, and outcomes of the current population of Athletic Training Education PDs. Potential findings may indicate a need to reexamine the current requirements necessary to hold the position of PD.

\section{Purpose of the Study}

The purpose of the investigation was to examine the relationships between selected characteristics and leadership outcomes of Athletic Training PDs. The characteristics of PDs that were examined in this investigation are based on the present requirements, or lack thereof, to become a PD and included academic preparation, accreditation experience, and leadership training history. Leadership outcome is a 
composite of three measures (follower extra effort, leader effectiveness, and follower satisfaction) obtained from the MLQ.

\section{Research Question}

Are specific characteristics (academic preparation, accreditation experience, and leadership training history) related to overall leadership outcome as measured by the MLQ independently of each other?

\section{Significance of the Study}

The significance of this study is twofold. First, it will establish the leadership characteristics and effectiveness of the current population of PDs. To date, this type of information has not been published in the literature. Second, the characteristics shown to have a positive relationship to the leadership effectiveness of the PD can be determined. This information can be used to assist the CAATE in strengthening the requirements necessary to hold the position of $\mathrm{PD}$, to assist administration in hiring more qualified PDs, and to assist those Athletic Trainers aspiring to become a PD better prepare for the position. Each PD can also use the results to improve the effectiveness of his or her own leadership by identifying and addressing areas of weakness.

\section{Operational Definitions}

For the purposes of this investigation, the following definitions will be used:

Athletic Training Education Program. A program that is accredited by the Commission on Accreditation of Athletic Training Education (CAATE) and prepares students to sit for the national Board of Certification examination to become a Certified Athletic Trainer. 
Athletic Training Education Program Director. Designated certified athletic trainer responsible for the organization and administration of all aspects of the educational program as mandated by the CAATE (CAATE, 2006).

Bass' Full Range of Leadership Model. A continuum of behaviors assessing one's leadership style through the Multifactor Leadership Questionnaire (MLQ). The model encompasses a leader's behavioral traits from transformational (growth-oriented and visionary), to transactional (exchange-based), to passive avoidant (the avoidance of leadership; Avolio\& Bass, 2004).

Certified Athletic Trainer. Allied healthcare professional certified through the Board of Certification, Inc. whose scope of practice includes meeting the healthcare needs of individuals involved in physical activity (National Athletic Trainers' Association, 2006).

Leadership. A process whereby an individual influences a group of individuals to achieve a common goal (Northouse, 2010).

Multifactor Leadership Questionnaire (MLQ.)An instrument that assesses both leadership style and outcomes of leadership (effectiveness). The MLQ contains 45 items that identify and measure key leadership and effectiveness behaviors that are strongly linked with both individual and organizational success (Avolio\& Bass, 2004).

\section{Delimitation of the Study}

The Multifactor Leadership Questionnaire is only one measure of leadership styles, behaviors, and outcomes. The leadership styles, behaviors, and outcomes used in this study are limited to those measured on the Multifactor Leadership Questionnaire. 


\section{CHAPTER 2}

\section{REVIEW OF LITERATURE}

The purpose of this review of the literature is to examine the leadership role of Athletic Training Program Directors and how it relates to models of leadership. There is currently no evidence describing what characteristics make an Athletic Training PD an effective leader. This investigation will describe the leadership styles, behaviors, and outcomes of the current population of Athletic Training Education PDs. The purpose of the investigation is to describe the relationships between selected characteristics and leadership outcomes. The characteristics that will be examined in this investigation are based on the present requirements, or lack thereof, to become a PD and include academic preparation, accreditation experience, and leadership training. The researcher feels the current requirements are too low and do not accurately represent the profession. Potential findings may indicate a need to reexamine the current qualifications necessary to hold the position of PD. This review of the literature will examine leadership, Bass' Full-Range of Leadership Model, leadership in higher education, Athletic Training education and research related to this investigation.

\section{Leadership}

Leadership can be viewed as the focus of group processes, from a personality perspective, or as an act or behavior. Leadership can also be defined in terms of the power relationship between leaders and associates, as an instrument of goal achievement, or from a skills perspective. Yet among all of these possible ways to define leadership, this study utilized Northouse's definition from his overview of leadership theory. Leadership is a process whereby an individual influences a group of individuals to 
achieve a common goal (Northouse, 2010).There are multiple leadership theories summarized here along with a description of their measures and utility. There are other theories of leadership, such as the great man theory or personality theory, but they are not discussed here because this study aligns more with a process understanding of leadership. Although leadership may be defined and measured in many different ways, it is best to select the most appropriate description and measurement of leadership for each environment.

\section{Situational Leadership}

Situational Leadership is a widely recognized approach that focuses on leadership in different situations. From this perspective, being an effective leader requires that an individual adapt his or her leadership style to the demands of different situations and different people (Northouse, 2010). The leader must match his or her leadership style to the competence and commitment of his or her subordinates using four behaviors: delegating, supporting, coaching, and directing. This approach requires the leader to be able to recognize the different needs of each subordinate and situation and to be flexible enough with his or her leadership behavior to be effective (Northouse, 2010).

Although this leadership approach has been widely used, the conceptualization is ambiguous and does not explain how to measure the subordinates' level of competence or commitment (Northouse, 2010). Also, this approach does not fully address the issue of one-to-one versus group leadership. It is not clear how the leader can approach each subordinate individually when working in an organizational setting, such as an educational institution. Finally, there is not one specific tool that is used to measure situational leadership. Questionnaires typically used ask the respondents to analyze 
various work-related situations and select the best leadership style for each situation. The answers available to the respondents are predetermined and therefore the questionnaires are biased in favor of situational leadership (Yukl, 1989). The Leadership Effectiveness and Adaptability Description (LEAD) instrument is one tool used to examine situational leadership. The LEAD questionnaire describes 12situations, and offers four possible leadership responses, one representing each of the four situational leadership styles for each situation. The participant's style range is determined by the number of times she or he selected each of the four styles: Telling, Selling, Participating, or Delegating, that align with the four quadrants of situational leadership. If a style is selected three or more times, it is considered part of the participant's leadership profile. Although this tool was consistently described in the literature, no validity or reliability was reported. This model does not fully address the issues of overall program leadership or effectiveness.

\section{Transformational Leadership}

Transformational leadership as measured by the Leadership Practices Inventory (LPI) is another common model of leadership. The LPI was first introduced by Kouzes and Posner in 1983 and has since become one of the most widely used leadership assessment instruments in the world. The authors developed a model of leadership that consists of The Five Practices of Exemplary Leadership: Model the Way, Inspire a Shared Vision, Challenge the Process, Enable Others to Act, and Encourage the Heart. The LPI contains 30 statements categorized into these five leadership practices. Each of the five leadership practices is defined by six leadership behaviors listed in the form of a statement on the instrument. Respondents rate their behavior regarding the extent to which they engage in each leadership behavior using the following scale: $1=$ almost 
never, $2=$ rarely, $3=$ seldom, $4=$ once in a while, $5=$ occasionally, $6=$ sometimes, $7=$ fairly often, 8 = usually, $9=$ very frequently, $10=$ almost always (Kouzes $\&$ Posner, 2007; Laurent \& Bradney, 2007). The LPI is reliable with high internal consistency (Cronbach $\alpha=.75$ to .87 ). The LPI is reported to have content and construct validity (regression analysis, $\mathrm{F}=318.88, p<.0001$, adjusted $\mathrm{R}^{2}=.756$; Kouzes $\&$ Posner; Laurent \&Bradney; Tourangeau \& McGilton, 2004).This model measures transformational leadership behaviors only and therefore can only be used as a guide to measure transformational leadership. It does not determine which leadership style the respondent most frequently exhibits; only how often the respondent exhibits transformational leadership behaviors.

In his seminal Pulitzer Prize-winning book, Leadership, James McGregor Burns (1978) first described leadership as two behaviorally dichotomous styles of transactional and transformational. Transactional leaders motivate associates by exchanging rewards for service while transformational leaders attempt to fully engage and motivate the associates in achieving a goal (Burns, 1978). A transformational leader differs from a transactional leader by not merely recognizing associates' needs, but by attempting to develop those needs from lower to higher levels of maturity (Avolio\& Bass, 2004). A leader may exhibit both transactional and transformational leadership in different situations. While these various theories are important in our understanding of leadership, a new paradigm, Full-Range of Leadership, was developed to describe leader-associate behavior at multiple levels of analysis (Avolio\& Bass, 2004). This theory is described in more detail and thus, this study aligns itself with Bass' model. 


\section{Bass’ Full-Range of Leadership Model}

Bass (1985a) proposed a model for the relationship between transactional and transformational leadership. The Full-Range of Leadership model broadens the range of leadership styles typically investigated, incorporating a continuum of behaviors to assess one's leadership style through the Multifactor Leadership Questionnaire (MLQ). The model encompasses a leader's behavioral traits from transformational (growth-oriented and visionary), to transactional (exchange-based), to passive avoidant (the avoidance of leadership). The Full-Range of Leadership model assesses a leader's performance on a range of leadership styles and illustrates the directions an individual may pursue to be a more effective leader. The advantage of the Bass' Full-Range of Leadership model and the MLQ is the $360^{\circ}$ capability that allows an investigator to assess leadership styles, behaviors, and effectiveness through various viewpoints.

Research indicates transformational leaders inspire others to produce higher levels of extra effort, effectiveness, and satisfaction (Avolio\& Bass, 2004). Transactional leadership provides a basis for effective leadership, but associates report a greater level of extra effort, effectiveness, and satisfaction under transactional leadership augmented with transformational leadership (Bass, 1985a). The leader displaying the optimal leadership profile will display more effective and active leadership behaviors that are primarily transformational with some transactional behaviors and will display these with greater frequency than the ineffective, inactive leadership behaviors of passive avoidant leadership. 


\section{Transformational Leadership Behaviors}

Transformational leaders are those who: (a) raise associates' level of awareness of the importance of achieving valued outcomes and the strategies for reaching them; (b) encourage associates to transcend their self-interest for the betterment of the team, organization, or larger policy; and (c) develop associates' needs to higher levels in such areas as achievement, autonomy, and affiliation, which may or may not be work related (Bass, 1985a; Bass, 1985b). Transformational leadership encourages others to develop and perform beyond standard expectations. The following transformational leadership behaviors are measured on the MLQ (Avolio\& Bass, 2004).

Idealized influence (attributes and behaviors).These leaders are trusted, admired, and respected by their associates and consider his or her associates needs over his or her own needs. In addition to sharing risks with their associates, these leaders demonstrate consistent conduct in regards to ethics, principles, and values. Attributes associated with these leaders include: instilling pride in others, putting the good of the group ahead of self-interest, acting in ways that build respect for them, and displaying a sense of power and confidence. Behaviors associated with these leaders include: discussing their most important values and beliefs, stating the importance of having a strong sense of purpose, reflecting on the moral and ethical consequences of decisions, and stressing the importance of having a collective sense of mission.

Inspirational motivation. These leaders motivate their associates by providing meaning and challenge to their work. Associates are encouraged to envision an attractive future and this arouses individual and team spirit. Enthusiasm and optimism are displayed in the workplace. These leaders exhibit these behaviors by talking optimistically about 
the future, talking enthusiastically about satisfying needs, articulating a compelling vision of the future, and expressing confidence in goal achievement.

Intellectual stimulation. These leaders stimulate their associates' effort to be innovative and creative by challenging assumptions, reframing problems, and examining prior situations in new ways. New ideas and creative solutions to problems are solicited from associates, and there is little public criticism of ideas or mistakes. Behaviors of these leaders include: questioning whether critical assumptions are appropriate, searching for differing perspectives when problem solving, encouraging associates to look at problems through different lenses, and suggesting new ways to complete assignments. Individual consideration. These leaders act as mentors and/or coaches to their associates, paying attention to each individual's needs for growth and achievement. The workplace environment is supportive and new learning opportunities are presented. Individual differences are accounted for and recognized. Behaviors of these leaders include: spending time teaching and mentoring, treating associates as individuals and not just as members of a group, considering each individual as having different needs, abilities, and aspirations, and assisting in developing the strengths of each associate.

\section{Transactional Leadership Behaviors}

Bass described transactional leaders in military, industrial, public, and educational sectors (Bass, 1985a; Bass 1985b). Transactional leaders are those who: (a) recognize what their associates want to get from their work, and try to see that they achieve it, if their performance warrants; (b) exchange rewards and promises of reward for appropriate levels of effort; and (c) respond to the needs and desires of associates as long as they are getting the job done (Bass, 1985a; Bass, 1985b). Transactional leadership can also be 
described as working with individuals or groups, setting up and defining agreements or contracts to achieve specific work objectives, discovering individual capabilities, and specifying the compensation and rewards that can be expected upon successful completion of the tasks. The following transactional leadership behaviors are measured on the MLQ (Avolio\& Bass, 2004).

Contingent reward. In an effort to achieve expected levels of performance, these leaders set expectations for their associates in the form of goals and objectives and offer recognition when these expectations are met. Behaviors of these leaders include:

providing assistance in exchange for associates' efforts, specifying who is responsible for reaching performance targets, making clear the reward for achieving the set expectations, and expressing satisfaction when associates meet expectations.

Management-by-exception: active. These leaders set the standards for compliance and identify what constitutes ineffective performance. They may punish associates who do not comply with the standards. These leaders closely monitor their subordinates for mistakes, errors, and deviances and take corrective actions as soon as they occur. Behaviors of these leaders include: focusing attention on mistakes, irregularities, and deviations from the standards, dealing with and documenting complaints and failures, and correcting failures to meet set standards.

Passive Avoidant Leadership Behaviors

Leaders who exhibit passive avoidant behaviors tend to be more reactive than proactive and do not respond to situations systematically. Passive leaders avoid specifying agreements, clarifying expectations, and providing goals and standards to be achieved by associates. This type of leadership has a negative effect on desired outcomes. 
The following passive avoidant leadership behaviors are measured on the MLQ (Avolio\& Bass, 2004).

Management-by-exception: passive. These leaders are similar to transactional, active management-by-exception leaders: however, they do not interfere until problems become serious. These leaders do not take action until something goes wrong or a failure occurs. They believe that problems must become chronic before an intervention is needed.

Laissez-faire. These leaders tend to be absent when needed and avoid getting involved when important issues arise. They avoid decision-making and may delay responding to urgent questions. These leaders provide little, if any, support to their associates.

Leadership Outcomes

Transformational and transactional leadership are both related to the effectiveness of an organization. Effectiveness is measured by how often the associates perceive their leader to be motivating, how effective associates perceive their leader to be at interacting at different levels of the organization, and how satisfied associates are with their leader's methods of working with others. The following leadership outcomes are measured on the MLQ (Avolio\& Bass, 2004).

Extra effort. This involves the leaders' ability to heighten the desire to succeed among their associates. It entails getting others to do more than they expected to do and increases their willingness to try harder.

Effectiveness. This involves the leaders' effectiveness in meeting the job-related needs of others, in representing the group to higher authorities, and in meeting 
organizational requirements. This also involves the leader's ability to guide an effective group.

Satisfaction with the leadership. This involves the leaders' ability to use methods that are satisfying to their associates and to work alongside them in a satisfactory way.

Both descriptive and statistical data analysis are commonly used with the MLQ. Descriptive statistics include the frequency in which the leader exhibits each leadership style (transformational, transactional, and passive avoidant); the frequency in which the leader exhibits each of the nine specific leadership behaviors; and the frequency in which the leader exhibits each leadership effectiveness outcome (follower extra effort, leader effectiveness, and follower satisfaction). Pearson product-moment correlations are commonly used to present the degree of association between the three leadership styles, the nine leadership behaviors, and the three leadership outcomes.

\section{Leadership in Higher Education}

Historically, transformational leadership may be less predominant in American public universities due to the fact that they are organizations embedded in state bureaucracy, enmeshed in union rules and contracts, and laden with departmental and faculty norms and traditions (Bass, 1985a). Those who pursue change in higher education institutions must contend with strong resistance, which takes the form of time and laborintensive processes and reviews (Birnbaum, 1991). College and university campuses must find ways to deal with a more diverse and non-traditional student population, a rapidly changing information technology age, and increasing competition for resources and enrollment. Transformational leaders can bring about change in the higher education institutions they are leading (Fisher, 1994). Program Directors (PDs) in the health 
professions are increasingly recognized as facilitators of learning and the education process and will play key leadership roles in ways that go beyond managing resources and applying standards and guidelines (Bordage, Foley, \&Goldyn, 2000; Nowicki, 1996).

Academicians play both a transactional and transformational role within an educational institution (Peer \& Rakich, 2000). PDs may act as transactional leaders on a daily basis. This type of leadership may include: the "simple exchange" of information and skills to students, interacting with colleagues and students regarding their role in promoting the educational development of the students, and ensuring quality educational practices (Peer \& Rakich, 2000; Ray, 2000). Specific examples of transactional leadership may be updating students and staff on changes to the program or reminding them of upcoming deadlines and events, conducting a monthly program meeting, or evaluating a faculty member's teaching.

Transformational leadership should also be part of the PDs role. As educators and administrators, transformational leaders use "change and conflict" to achieve quality standards in the professional development of students and colleagues (Peer \& Rakich, 2000; Ray, 2000). Specific examples of transformational leadership may include modifying an existing evaluation process to obtain more useful feedback, developing and initiating an action plan to acquire additional resources and/or clinical education opportunities, or encouraging and promoting professional development activities for faculty and students. In order to be successful, a PD must have a clear vision for his or her program and the vision must be consistent with the goals and missions of their program and institution (Peer \& Rakich, 2000). 


\section{Athletic Training Education}

Athletic Training was officially recognized by the American Medical Association as an allied health profession in 1990. Certified Athletic Trainers (ATs) are allied healthcare professionals whose scope of practice includes meeting the healthcare needs of individuals involved in physical activity (National Athletic Trainers' Association, 2006). The first undergraduate Athletic Training Education Programs were recognized in 1969. A year later, the first National Athletic Trainers' Association (NATA) certification examination was administered. At that time, there were four avenues through which eligibility for certification as an Athletic Trainer could have been attained. They included graduation from a NATA-approved Athletic Training Education Program, completion of an internship program, graduation from a school of physical therapy, and a special consideration route (Delforge \& Behnke, 1999). Over the ensuing years, the possible routes to certification eligibility dwindled and, with the elimination of the internship route on December 31, 2003, only one certification route remains. This remaining avenue is graduation from a Commission on Accreditation of Athletic Training Education (CAATE) accredited entry-level program, either at the undergraduate or graduate level. The purpose of the CAATE is to develop, maintain, and promote appropriate minimum standards of quality for educational programs in Athletic Training. It is the responsibility of an institution to demonstrate compliance with the CAATE Standards for the Accreditation of Entry Level Educational Programs in order to obtain and maintain recognition as a CAATE-accredited program (CAATE, 2006). The Athletic Training Education Program Director (PD) is the individual responsible for the organization and administration of all aspects of the educational program as mandated by the CAATE and 
serves as a leader to the faculty, staff, and students within their program. As of 2009, there were 346 CAATE accredited undergraduate and 20CAATE accredited entry-level graduate degree Athletic Training Education Programs in the United States and several more programs were applying for accreditation. At the end of 1997, there were only 82 accredited programs, resulting in an increase of over $300 \%$ (CAATE, 2007). The implementation of a single route to certification amplified the emphasis placed on hiring and retaining full-time Athletic Training faculty (Starkey \& Ingersoll, 2001). Specifically, with the increase in the number of CAATE-accredited Athletic Training Education Programs in colleges and universities, the demand for a qualified faculty member to serve as the PD and fill the multiple roles and responsibilities of the position increased (Perkins \& Judd, 2001).

Roles and Responsibilities of the Program Director

In the past two decades, the position of PD has undergone considerable changes in administrative responsibilities and institutional expectations (Perkins \& Judd, 2001). The duties and responsibilities of PDs are multiple and highly diversified. These include, but are not limited to: curriculum planning and development; fiscal and budgetary input and management as determined by the institution; distribution of educational opportunities at all clinical and classroom sites; and recognizable institutional responsibility or oversight for the day-to-day operation, coordination, supervision, and evaluation of all components of the Athletic Training Education Program (CAATE, 2006). In addition to the minimal CAATE requirements, the PD is involved in recruiting and retaining students, mentoring, advising, assessing, resolving conflicts, innovating and monitoring change, supervising 
students and staff, abiding by and applying regulations, preparing accreditation materials, and teaching (Bordage, Foley, \&Goldyn, 2000; Judd \& Perkins, 2004).

The current CAATE standards require that the PD be a full-time employee of the sponsoring institution and have faculty status, rights, responsibilities, and privileges as defined by institution policy, consistent with other similar positions at the institution. The PD must also have programmatic administrative and supervisory responsibility recognized as a department assignment consistent with other similar assignments at the institution and must have an amount of released/reassigned workload that is necessary to meet the administrative responsibilities of the assignment, also consistent with similar assignments at the institution. The PD must also hold current national certification as an Athletic Trainer; have a minimum of 5 years of experience as a Board of Certification, Inc. certified AT; must possess a current state Athletic Training credential for those states that require professional credentialing; and must demonstrate teaching, scholarship, and service consistent with institutional standards (CAATE, 2006).

Although a PD must possess a Bachelor's degree and have a minimum of 5 years of experience as a Certified Athletic Trainer, the standards do not require this experience to be in any particular work setting. There is no requirement for the PD to have experience working in a didactic setting or in higher education. Due to the differences in job responsibilities, it is unlikely that an Athletic Trainer who has worked for at least 5 years in the clinical setting would possess the necessary skills to be an effective leader within the academic setting. The academic setting requires specific skills that are much different from the clinical setting and are not typically represented in Athletic Training Education Programs. Experiences that may impact a PDs leadership style and 
effectiveness include holding a faculty member position within an Athletic Training Education Program, working as a graduate or doctoral assistant within an entry level Athletic Training Education Program, or being a PD for a certain length of time. There is no research providing evidence as to how academic preparation impacts the leadership outcomes of a PD.

In 1997, the NATA Education Task Force made several recommendations to reform Athletic Training Education (NATA, 1997). Included within these recommendations were three reasons to develop more doctoral-educated ATs:(a) to increase the number of doctoral-educated ATs in senior faculty and administrative positions to affect higher education policy,(b) to provide leadership in guiding research pertinent to the advancement of the Athletic Training profession, and (c) to provide the next generation of Athletic Training educators (NATA, 1997). However, this recommendation has not been translated to the requirements to be a PD.

Currently, the NATA does not endorse specific doctoral education programs for ATs. Although there are few universities that grant a doctorate in Athletic Training, there are several universities that provide research infrastructure, educational opportunities, mentorship, and financial compensation to ATs (NATA Education Council, 2007). Researchers have recommended that those ATs aspiring to become PDs earn a terminal degree (Leard, Booth, \& Johnson, 1991). Doctoral programs designed specifically for ATs must continue to evolve. In conjunction with educational facets and advanced clinical knowledge, an Athletic Training doctoral program should also provide the student with thorough research, leadership, and administrative training to prepare the individual for a career in higher education (Hertel, West, Buckley, \& Denegar, 2001). 
Educational reform in the profession of Athletic Training has also raised the demands of PDs and their colleagues to adapt to changing didactic and clinical accreditation standards (Mangus, 1998).The CAATE encourages institutions to develop programs that substantially exceed the Standards for the Accreditation of Entry Level Educational Programs for the Athletic Trainer through development of sound, innovative educational approaches (CAATE, 2006). The CAATE's Comprehensive Review for Accreditation Process, when utilized to its fullest potential, allows an educational program to critically examine, in structure and substance, its overall effectiveness relative to its mission and outcomes and to assist the institution in determining necessary programmatic modifications and improvements (CAATE, 2006). The role of the PD in attaining and maintaining accreditation status has definite implications on the operation and success of athletic training education programs (Peer \& Rakich, 2000). Effective leadership is critical to obtaining and maintaining accreditation because the initial investment in time alone is extensive; however, it is necessary to ensure that each aspect of the process is carefully analyzed to maximize the potential for success (Shaw, 1993). Allied health professions need leaders who are committed to his or her profession, can make decisions, have a vision, can share values, and are able to inspire and empower others (Dunham \& Klaffen, 1990). The future of health care professions, including Athletic Training, may depend on the development and advancement of leaders who can respond to the challenges of the accreditation process (Short, 1997).

An Athletic Training PD is not required to have any previous leadership training. Leadership training is designed to cultivate the leadership skills and abilities of an individual. Leadership training may be in the form of academic coursework or degree, 
workshops, seminars, conferences, or online training. Although individuals may develop their leadership potential and skills throughout their lives, structured leadership activities are designed to foster and enhance leadership skill (Fredricks, 1998). There is no research providing evidence as to whether or not having a history of leadership training impacts the leadership outcomes of a PD. Data from the MLQ is commonly used to assist in the development and implementation of leadership training activities. Information obtained on the specific leadership training experiences of effective Athletic Training PDs may be useful in the development of leadership training experiences specifically designed for Athletic Training PDs.

\section{Related Research in Higher Education}

Research has shown that transformational leadership is found within different positions at colleges and universities. Studies with subjects from faculty (Kuchinke, 1999), department chairs (Archie, 1997; Footit, 2000), academic deans (King, 1994), university presidents (Levine, 2000), and board of trustees chairs (Clos, 1997) have shown that there are individuals at each of these administrative levels who exhibit transformational leadership traits.

A study of nursing department heads showed that transformational leadership behaviors were associated with statistically higher levels of perceived leader effectiveness, faculty satisfaction, and a greater willingness of the faculty to put forth extra effort (Archie, 1997).Levine (2000) found that transformational leadership is the most frequently found leadership style among presidents of the top 50 national universities as ranked by the U.S. News \& World Report and those transformational leaders were found to induce the greatest satisfaction among the top administrators 
surveyed using the MLQ. Using the MLQ, Clos (1997) studied Texas community college board chairs and found they believed their own leadership style to be highly transformational. Other raters in this study, chief executive officers and board colleagues, also rated the board chair as being highly transformational (Clos, 1997).

Evidence indicates the MLQ factors can be universally applied in any organization or culture (Avolio\& Bass, 2004). Bass' Full-Range of Leadership model and the MLQ have been used within the profession of Athletic Training in one investigation (Zuest, 2003). Results of this study suggested that PDs perceived themselves as utilizing the five transformational leadership behaviors and the transactional behavior of contingent reward to a greater degree than the other transactional leadership behaviors and passive avoidant leadership behaviors (Zuest, 2003). Regression analysis revealed five significant relationships between the three leadership outcomes, the nine leadership behaviors, and four measures of leadership experience (years served as a faculty member in an Athletic Training Education Program, years served as PD at current institution, years served as PD of any institution, years served as an administrator in a higher education institution). Inspirational motivation was significantly related to all three leadership outcomes, while idealized influence was significantly related to follower's satisfaction, and contingent reward was significantly related to leader's effectiveness. These relationships suggest that as the use of these leadership behaviors increases so does the outcome measure. No relationships were found between leadership outcomes and leadership experience measures (Zuest, 2003).

At the time of the Zuest investigation there were only 182 accredited Athletic Training Education Programs. In addition, Zuest utilized a paper-based survey, which 
garnished a $58 \%$ return rate. When given an option of responding to a study on leadership behaviors via web-based survey, e-mail survey, or traditional paper survey, 95\% of respondents chose the web-based survey (Laurent \& Bradney, 2007).

Recommendations from previous studies examining the leadership behaviors of PDs recommended that web-based surveys be used for data collection (Zuest, 2003; Laurent \& Bradney, 2007). The PD will complete the MLQ rating him or herself on how frequently, or to what degree, the PD engages in specific behaviors using a web-based system. The total number of programs has increased considerably since 2004 and the current investigation will attempt to profile the current population of PDs. A web-based survey will be utilized, which may increase the return rate.

Conclusion

Administering the MLQ to Athletic Training Education PDs will give the investigator data on the PD's self-perceived leadership characteristics. These data include: the leadership style most utilized by the PD (transformational, transactional, or passive avoidant) and the specific leadership behaviors most utilized by the PD (idealized influence [attributed], idealized influence [behavior], inspirational motivation, intellectual stimulation, individualized consideration, contingent reward, management-by-exception [active], management-by-exception [passive], and laissez-faire). The effectiveness of the PD's leadership (follower extra effort, leader effectiveness, and follower satisfaction) will be described in relation to selected characteristics. Analysis may suggest areas of strengths and weakness within the PD's leadership. The PD can then focus his or her attention on improving leadership within the weak areas. 
The development of management theory, which includes leadership, has been virtually ignored in Athletic Training Education Programs (Rankin \& Ingersoll, 1995). There is no requirement for an Athletic Training Education PD to have a background or training, either formal or informal, in leadership. Athletic Training program improvement and organizational success requires transformational leadership and those who rely solely on transactional or passive-avoidant leadership will probably not thrive (Ray, 2000). A PD must be aware of his or her self-perceived leadership style, as well as know how others perceive his or her leadership style, to be an effective leader (Hoy \& Miskel, 1996). This study will attempt to add to the very limited literature on Athletic Training Education PD leadership styles, behaviors, and outcomes. 


\section{CHAPTER 3}

\section{METHODS}

\section{Research Design}

This investigation utilized an ex post facto research with hypotheses design utilizing surveys to assess the leadership styles and leadership behaviors of the current population of Athletic Training Education Program Directors (PDs). This type of design is stronger in regards to internal validity than ex post facto research without hypotheses (Newman \& Newman, 1994). The purpose of the investigation was to examine the relationships between selected characteristics and a leadership outcome measure of Athletic Training PDs. The characteristics of PDs that were examined in this investigation were based on the present requirements, or lack thereof, to become a PD and included academic preparation, accreditation experience, and leadership training history. Leadership outcome is a composite of three measures (follower extra effort, leader effectiveness, and follower satisfaction) obtained from the MLQ. Due to limited previous research on this subject, non-directional hypotheses were used. The formal research question and hypotheses addressed in this investigation were:

Research

Question:

Are specific characteristics (academic preparation, accreditation experience, and leadership training history) related to overall leadership outcome as measured by the MLQ?

Hypothesis \#1: There will be a significant difference between levels of academic preparation (undergraduate, graduate, and doctoral degrees) in predicting overall leadership outcome as measured by the MLQ independent of accreditation experience and leadership training history. 
Hypothesis \#2: There will be a significant difference between years of accreditation experience in predicting overall leadership outcome as measured by the MLQ independent of academic preparation and leadership training history.

Hypothesis \#3: There will be a significant difference between leadership training histories in predicting overall leadership outcome as measured by the MLQ independent of academic preparation and accreditation experience.

\section{Participants}

The population used in this study was limited to the PDs of all accredited entry-level Athletic Training Education Programs in the United States. Institutions were identified using the list of accredited Athletic Training Education Programs posted on the Commission on Accreditation of Athletic Training Education (CAATE) website (www.caate.net). At the time of the study, there were 366 possible participants. The study was approved by the Florida International University Institutional Review Board.

\section{Variables}

The independent variables in this investigation were 1) academic preparation, 2) accreditation experience, and 3) leadership training history as determined by the demographic questionnaire completed by each leader (Appendix A). The dependent variables in this investigation were the scores of overall leadership outcome, developed from follower extra effort, leadership effectiveness, and follower satisfaction as measured by the MLQ. 


\section{Instrument}

The investigation utilized the Multifactor Leadership Questionnaire (MLQ version 5X-Short). The MLQ is a tool composed of 45 items that identify and measure key leadership and effectiveness behaviors shown in prior research to be strongly linked with both individual and organizational success (Avolio \& Bass, 2004). It should have taken each leader approximately 15 minutes to complete the questionnaire.

The MLQ was chosen for use in this investigation because of the broad range of leadership styles and behaviors it examines. The MLQ is one of few instruments that assesses both leadership style and outcomes of leadership (effectiveness). The items on the MLQ are broadly applicable to a variety of organizations and professions, including Athletic Training (Zuest, 2003). The leader completing the MLQ indicates how frequently, or to what degree, they have engaged in 36 specific behaviors. Each of nine leadership components along a full-range of leadership styles is measured by four highly inter-correlated items that are as low in correlation as possible with the items of the other eight components (Avolio \& Bass, 2004). Each of three components of leadership outcomes (follower extra effort, leader effectiveness, and follower satisfaction) is measured by three additional items on the MLQ. The MLQ has reported reliabilities for each of the scales ranging from .74 to .94 (Avolio \& Bass, 2004).

Bass' leadership model includes nine distinct leadership behaviors that form a continuum and includes five transformational behaviors (idealized influence [attributed], idealized influence [behavior], inspirational motivation, intellectual stimulation, individualized consideration), two transactional behaviors (contingent reward, management-by-exception [active]), and two passive avoidant behaviors (management- 
by-exception [passive], and laissez-faire). The leader uses a 5-point scale to rate the frequency of each behavior. The rating scale used is: 0 (not at all), 1 (once in a while), 2 (sometimes), 3 (fairly often), and 4 (frequently, if not always).

The MLQ also measures three leadership outcomes which occur as a consequence to the leader's preferred behavior: follower extra effort, leader effectiveness, and follower satisfaction (Avolio \& Bass, 2004). Examples of questions that contribute to these factors include: "I heighten others' desire to exceed", "I am effective in representing others to higher authority", and "I work with others in a satisfactory way". The leader uses the same 5-point scale to rate the frequency of each outcome. The rating scale used is: 0 (not at all), 1 (once in a while), 2 (sometimes), 3 (fairly often), and 4 (frequently, if not always).

\section{Procedures}

The email address for each PD was obtained from the CAATE website. The researcher sent an email to each academic PD requesting his or her participation in this study. The purpose of the study and an explanation of the PD's role in the study were contained in the body of the email. If the PD agreed to participate, he or she was instructed to reply to the initial email and complete the demographic questionnaire attached to the email. The demographic questionnaire was used to obtain the leader's academic preparation, accreditation experience and leadership training history.

The researcher emailed the PDs who agreed to participate in the study a survey webpage created by Mind Garden, Inc. The PDs completed the MLQ survey. Two weeks from the initial email, a reminder was sent to those who did not respond to the request for participation. A reminder was also be sent to those who did agree to participate but who 
had not completed the surveys approximately 2 weeks after receiving the survey webpage. Reminder emails and additional requests for participation were sent out four more times.

\section{Statistical Analysis}

Statistical analysis for the quantitative data was completed in Statistical Package for Social Sciences (SPSS 18.0) utilizing descriptive statistics and nonparametric tests (Avolio \& Bass, 2004; Hinkle, Wiersma, \& Jurs, 2003). Descriptive statistics include the frequency with which the leader reported exhibiting each leadership style (transformational, transactional, and passive avoidant); the frequency with which the leader reported exhibiting each of the nine specific leadership behaviors; and the frequency with which the leader reported exhibiting each leadership outcome (follower extra effort, leader effectiveness, and follower satisfaction).

Mann-Whitney U tests and Spearman's Rho correlations were used to determine the relationships between selected characteristics and leadership outcome. The selected characteristics include academic preparation, accreditation experience, and leadership training history. The alpha level was set at .05 . 


\section{CHAPTER 4}

\section{RESULTS}

An initial email request and several additional email requests for participation were sent to the Program Director (PD) of each CAATE accredited program $(n=346)$. A total of 40 PDs returned the demographic questionnaire and agreed to participate.

However, of those who agreed to participate, only 27 completed the MLQ.

The independent variables in this investigation were 1) academic preparation, 2) accreditation experience, and 3) leadership training history. These variables were chosen based on the current requirements necessary to become an Athletic Training Education PD. There is a need to examine and possibly modify the current requirements because these requirements are not equivalent to other similar professions. In addition, gender differences were considered as gender differences are often reported in leadership research, A meta-analysis of 45studies of transformational, transactional, and laissez-faire leadership styles found that female leaders were more transformational than male leaders (Eagly, Johannesen-Schmidt, \& van Engen, 2003).

Of the 27 participants, $18(66.7 \%)$ were female and 9 were male $(33.3 \%)$. The ages of the participants ranged from 30 to 59 years, with the mean age of 39.9 years. The number of years certified as an Athletic Trainer ranged from 8 to 35 years, with a mean of 17.2 years. The number of years as the PD at the current institution ranged from 1 to 20 years, with a mean of 6.4 years and number of years as a PD overall ranged from 1 to 24 years, with a mean of 7.3 years.

The highest degree earned was a master's degree for $9(33.3 \%)$ of the participants, while 18 participants $(66.7 \%)$ had earned a doctorate degree. Only one participant had a 
doctorate degree in Athletic Training. The total number of years of active participation in athletic training accreditation related activities ranged from 4 to 20 years, with a mean of 10.6 years. There was no definition provided for active participation and participants may have viewed the question differently from each other. Also, participants were asked to indicate the number of years they have actively participated in Athletic Training accreditation related activities in varying roles. However, the questionnaire did not take into account that participants may have held more than one role simultaneously.

Leadership training history consisted of two components - academic coursework on leadership and continuing education and additional activities pertaining to leadership. Of the 27 participants, 14 had completed academic coursework on leadership, with the number of credit hours ranging from 1 to $36($ mean $=9.6)$. Thirteen participants had not completed any academic coursework on leadership. Twenty-one participants had completed continuing education or additional activities pertaining to leadership, while 6 had not completed any continuing education or additional activities pertaining to leadership.

\section{Leadership Profile}

Table 1provides the means and standard deviations of the PDs composite scores for each of the three leadership styles included in Bass' Full-Range of Leadership model. Overall, the PDs utilized transformational leadership most often and passive avoidant leadership least often. Of the 27 participants, 26 indicated utilizing transformational leadership most frequently and one participant indicated utilizing transactional leadership most frequently. 
Table 1

PD Leadership Styles

\begin{tabular}{lcc}
\hline \multicolumn{1}{c}{ Style } & Mean & SD \\
\hline & 3.18 & 0.34 \\
Transformational Leadership & & \\
Transactional Leadership & 2.34 & 0.38 \\
& & \\
Passive Avoidant Leadership & 0.8 & 0.59 \\
\hline
\end{tabular}

Table 2 provides the means and standard deviations of the study's PDs' composite scores on the nine specific leadership behaviors included in Bass' Full-Range of Leadership model. The most commonly utilized leadership behaviors were individual consideration, inspirational motivation, and idealized influence. The least commonly utilized leadership behaviors were management-by-exception and laissez-faire. 
Table 2

PD Leadership Behaviors

\begin{tabular}{|c|c|c|}
\hline Behavior & Mean & SD \\
\hline Individual Consideration & 3.41 & 0.42 \\
\hline Inspirational Motivation & 3.26 & 0.5 \\
\hline Idealized Influence (Behaviors) & 3.16 & 0.53 \\
\hline Idealized Influence (Attributes) & 3.06 & 0.47 \\
\hline Intellectual Stimulation & 3 & 0.44 \\
\hline Contingent Reward & 2.94 & 0.47 \\
\hline Management-by-Exception: Active & 1.7 & 0.63 \\
\hline $\begin{array}{l}\text { Management-by-Exception: } \\
\text { Passive }\end{array}$ & 0.97 & 0.76 \\
\hline Laissez-Faire & 0.6 & 0.58 \\
\hline
\end{tabular}

Table 3provides the means and standard deviations of the study's PDs' composite scores on the three components of leadership outcome and overall leadership outcome. The PDs indicated utilizing the effectiveness component of leadership outcome most often and the extra effort component least often. 
Table 3

PD Leadership Outcomes

\begin{tabular}{lcc}
\hline \multicolumn{1}{c}{ Outcome } & Mean & SD \\
\hline Effectiveness & 3.36 & 0.43 \\
Satisfaction with the leadership & 3.28 & 0.53 \\
Extra Effort & 2.81 & 0.67 \\
& & \\
Leadership Outcome & 3.15 & 0.43 \\
\hline
\end{tabular}

Hypotheses Testing

An independent Mann-Whitney $U$ test determined there was no significant difference between PD's with master's and doctorate degrees on overall leadership outcome. However, participants with a doctorate degree scored significantly different on the effectiveness component of leadership outcome compared with participants with a master's degree (Table 4). This is an important finding because with such a small sample size, it was highly probable that no significance would be found. There was no significant correlation between years of accreditation experience and leadership outcome (Table 5). 
Table 4

Mann-Whitney U Test for Masters/Doctorate Degree

Outcome $p$

Effectiveness $\quad .046^{*}$

Satisfaction with the leadership $\quad .176$

Extra Effort $\quad .322$

Leadership Outcome $\quad .095$

$*_{p}<.05$

Table 5

Spearman's Rho Correlation for Accreditation Experience and Leadership Outcome

\begin{tabular}{lcccc}
\hline & Effectiveness & $\begin{array}{c}\text { Satisfaction } \\
\text { with the } \\
\text { Leadership }\end{array}$ & Extra Effort & $\begin{array}{c}\text { Leadership } \\
\text { Outcome }\end{array}$ \\
\hline Accreditation Experience & & & & \\
Correlation Coefficient & .234 & .147 & .001 & .168 \\
$p$ & .241 & .463 & .998 & .403 \\
$\mathrm{~N}$ & 27 & 27 & 27 & 27 \\
\hline
\end{tabular}

$* p<.05$

An independent Mann-Whitney $U$ test determined that those participants who have completed academic coursework on leadership scored significantly different on leadership outcome compared to those who have not completed academic coursework on leadership (Table 6). Leadership skills and behaviors can be learned. Previous research has shown that structured leadership activities can enhance leadership skill (Fredricks, 1998). Therefore, this is an important finding, as it justifies the need for including leadership training as a requirement to become an Athletic Training Education PD. 
Table 6

Mann-Whitney U Test for Academic Coursework

\begin{tabular}{lc}
\hline Outcome & $p$ \\
\hline Effectiveness & .202 \\
Satisfaction with the leadership & .076 \\
Extra Effort & .076 \\
Leadership Outcome & $.043^{*}$ \\
\hline
\end{tabular}

${ }^{*} p<.05$

An independent Mann-Whitney U test determined there was no significant difference between those participants who completed continuing education or additional activities on leadership and those who have not completed continuing education or additional activities on leadership (Table 7).

Table 7

Mann-Whitney U Test for Continuing Education

\begin{tabular}{ll}
\hline Outcome & $p$ \\
\hline Effectiveness & .441 \\
Satisfaction with the leadership & .670 \\
Extra Effort & .140 \\
Leadership Outcome & .408 \\
\hline
\end{tabular}

$*_{p}<.05$ 
An independent Mann-Whitney U test determined that women scored significantly different on leadership outcome than men. Women also scored significantly different on the components of effectiveness and extra effort (Table 8).

Table 8

Mann-Whitney U Test for Gender

\begin{tabular}{ll}
\hline Outcome & $p$ \\
\hline Effectiveness & $.041^{*}$ \\
Satisfaction with the leadership & .176 \\
Extra Effort & $.041^{*}$ \\
Leadership Outcome & $.011^{*}$ \\
\hline
\end{tabular}

$* p<.05$ 


\section{CHAPTER 5}

\section{DISCUSSION}

As the leader of an Athletic Training Education Program, the Program Director is charged with many roles and responsibilities. In addition to teaching, advising, and administrative duties, the PD must also ensure the program is adhering to accreditation standards. Although faculty loads may vary from institution to institution, the PD must effectively balance many roles in order for the program to flourish. Currently, the requirements to become a $\mathrm{PD}$ are minimal and may not reflect the needs of the position.

\section{Leadership Profile}

The leadership profile of the Athletic Training Education PDs in this study is consistent with the optimal leadership profile described by Bass. The PDs utilized transformational leadership most often, followed by transactional leadership, and passive avoidant leadership. The PDs utilized transformational leadership behaviors [individual consideration, inspirational motivation, idealized influence (behaviors), idealized influence (attributes), and intellectual stimulation] to a greater extent than transactional (contingent reward and management-by-exception: active) and passive avoidant (management-by-exception: passive and laissez-faire) leadership behaviors.

The use of transformational leadership and the associated behaviors may allow followers to develop a shared vision of the organization, have an increased self-worth, complete more challenging and meaningful work, and feel valued. This in turn, may lead to increased loyalty, increased organizational commitment, increased job satisfaction, increased morale and increased job performance (McGuire \& Kennerly, 2006). Overall, this may lead to a highly productive and successful program. 
Although gender was not a stated independent variable in this study, it is worth noting the findings as they relate to the literature. A meta-analysis of 45 studies of transformational, transactional, and laissez-faire leadership styles found that female leaders were more transformational than male leaders (Eagly, Johannesen-Schmidt, \& van Engen, 2003).This study found that females scored significantly different on leadership outcome, effectiveness, and extra effort compared to men. Although gender alone cannot be used as a requirement to become a PD, it may be used as a guideline in academic preparation, accreditation experiences, and development of leadership training activities specific to males and females.

\section{Academic Preparation}

All participants in this study had earned at least a master's degree and two-thirds had earned a doctorate degree. Although there was no significant difference in overall leadership outcome, those participants with a doctorate degree scored significantly higher on the effectiveness component of overall leadership. Due to the low N, this finding of significance was important. Of the three components of overall leadership outcome (extra effort, effectiveness, and satisfaction with the leadership), the effectiveness component relates most closely with the primary responsibilities of the PD. This component consists of items related to how effective the PD is in meeting the job-related needs of others, in representing the group to higher authority, in meeting organizational requirements, and in leading a group that is effective.

At the present time, the Commission on Accreditation of Athletic Training Education stipulates that only a bachelor's degree is required to become a PD. Some institutions may require a higher degree to serve as a faculty member and therefore may 
require a higher degree for the PD. The area of study for the master's and doctorate degrees of the participants varied widely. Earning a doctorate degree may be more important than the specific area of study. In addition to gaining additional clinical knowledge, a doctoral program may allow the student to foster skills in research, leadership, and administration (Hertel, West, Buckley, \& Denegar, 2001). This skill development may help prepare the Athletic Trainer for a career in Higher Education and for the role of PD.

Modifications to the Standards for the Accreditation of Entry-Level Athletic Training Education Programs have strengthened the position of the PD, yet the qualifications required to serve as a PD fall short of other health care professions. Compared to Nursing and Physical Therapy, Athletic Training is a relatively new profession and is still striving for recognition and respect. To gain equal stature, Athletic Training PDs must be held to standards comparable to other health care professions. The Standards for Accreditation of Baccalaureate and Graduate Nursing Programs, outlined by the Commission on Collegiate Nursing Education, require the Chief Nursing Administrator to be a registered nurse holding a graduate degree (Commission on Collegiate Nursing Education, 2007). The Commission on Accreditation in Physical Therapy Education, the accrediting body for physical therapy programs, outlines in great detail the requirements for a Program Administrator, who must possess a doctoral degree (Commission on Accreditation in Physical Therapy, 2006).

Athletic Training PDs must only possess a bachelor's degree, which at this time, is the entry-level degree for the profession. Athletic Training Education Programs culminating in a bachelor's degree or entry-level master's degree may not prepare 
students for the leadership responsibilities and challenges they may face as a PD. In this study, PDs with a doctorate degree scored significantly higher on the effectiveness component of leadership outcome, indicating they may be better prepared to meet the job-related needs of their followers, to represent the program to higher authorities, to meet organizational requirements, and to lead a group that is effective. Requiring a PD to earn a doctorate degree can significantly add to the quality of his or her leadership. It is not just in regards to degree inflation, but better quality leadership can lead to an overall enhanced Athletic Training Education Program. This study provides evidence to justify the raising of standards for the position of PD. Considering the greater effectiveness among those with an earned doctorate, future research should focus more specifically on the type of degree, degree subject area, and the educational experiences of graduate and doctoral students. Identifying the specific types of degree, subject area, and experiences that produce more effective leaders can assist in the development of doctorate programs geared toward those Athletic Trainers wanting to become PDs.

\section{Accreditation Experience}

The number of years of participation in accreditation related activities did not have a significant effect on overall leadership outcome. An Athletic Trainer may participate in accreditation related activities in many roles, including as a PD, as a Clinical Coordinator, as a faculty member, as an Approved Clinical Instructor, or as a Graduate or Doctoral Assistant. The current guidelines do not stipulate that the PD have any experience with accreditation related activities. An important role of the PD is to attain and maintain accreditation status. Peer and Rakich (2000) indicate a PD with no prior accreditation experience may have difficulty fulfilling this role, which could lead to 
definite implications on the operation and success of athletic training education programs. The findings of the current research study contradict this statement. However, the data may not be truly representative due to the lack of a definition for active participation in accreditation activities on the demographic questionnaire. Future surveys should include a clear definition of active participation in accreditation related activities.

Although there were no significant findings related to accreditation experience, all participants had some experience actively participating in accreditation related activities. The number of years of participation ranged from 4 to 20 years, with a mean of 10.5 years. It is noted that the follow-up question on the demographic questionnaire may have been confusing to the participant. When asked to indicate the number of years they had participated in each of the listed activities, it is theorized that participants may have answered in different ways. For instance, some may have been participating in more than one type of activity at a time. Therefore, depending on how they answered the questions, the sum of the number of hours participated in each activity may or may not equal the total number hours of participation listed. It may be beneficial in the future to examine the roles held while gaining accreditation experience, the specific types of accreditation related activities, and their relationship to the leadership outcome of the PD.

\section{Leadership Training History}

In the present study, participants who had completed academic coursework on leadership scored significantly different on the overall leadership outcome composite score compared to those participants who had not completed any academic coursework on leadership. This significant finding should be considered when evaluating the current qualifications of a PD. It may be beneficial to require those who strive to be a PD to 
complete academic coursework on leadership. The number of credit hours completed by participants in this study ranged from one hour to 36 hours, with a mean of 9.6 hours. It is not known if the academic coursework was a requirement of a degree program or taken outside the scope of a degree program. Academic coursework has a significant effect on overall leadership outcome; therefore, future research may attempt to determine a description of the optimal type and amount of academic coursework recommended for a PD.

In this study, there was no significant difference between participants who completed continuing education or additional activities pertaining to leadership and those who had not completed any continuing education or additional activities pertaining to leadership. The overall mean for continuing education or additional activities was 12.4 hours. The three most common activities were attendance at a conference (mean of 5.2 hours), other (mean of 4.7 hours), and workshop (mean of 3.8 hours). It is not known if participants completed continuing education or additional activities due to motivation to develop their own leadership skills, to fulfill continuing education requirements or both. Specific content within the activities was not described and therefore may not be geared toward the role of PD.

There is no requirement for a PD to have any previous leadership education or training prior to becoming a PD. The Commission on Collegiate Nursing Education requires that the Chief Nurse Administrator provide effective leadership in achieving its mission, goals, and expected outcomes (Commission on Collegiate Nursing Education, 2003). An example of how effective leadership may be evidenced is through demonstration that the scope of authority of the Chief Nursing Administrator in decisions 
integral to the nursing program is comparable to that of administrators in similar academic units within the institution (Commission on Collegiate Nursing Education, 2007). The Commission on Accreditation in Physical Therapy Education also requires that Program Administrators provide effective leadership for the program (Commission on Accreditation in Physical Therapy, 2006). The Physical Therapy program must provide a description of the process utilized to assess the Program Administrator as an effective leader. Evidence of effective leadership may include: proven effective interpersonal and conflict-management skills; abilities to facilitate change; negotiation skills (relative to planning, budgeting, faculty and program status); and program accomplishments (Commission on Accreditation in Physical Therapy, 2006). The standards for an Athletic Training Education PD fail to address leadership. Because of the rapidly changing educational environment, leadership in Athletic Training has become an important issue facing the profession.

This investigation failed to provide evidence that having a history of leadership training positively impacts the leadership outcomes of a PD. Future research may describe the specific leadership training experiences that may be useful in the development of leadership training requirements specifically designed for Athletic Training PDs.

\section{Recommendations for Future Research}

Due to the nature of this study, self-rating may be a limitation. That is, leaders may include subjective opinions in the evaluation of their leadership. The current study only used self-reported ratings on the MLQ. However, in addition to the leader rating him or herself, it is recommended that persons working above, below, and directly at the same 
organizational level as the leader also rate the leader. Future research should include the ratings from a supervisor, peers, and students. This will allow for a $360^{\circ}$ view of the leadership styles, behaviors, and outcomes. In a survey of factors that affect ATs who work in accredited Athletic Training programs, over $80 \%$ of respondents agreed that evaluations provided by the chair of their department or head of their academic unit and student evaluations were the two most important criteria in their performance evaluations. Having multiple raters may limit the amount of rater bias associated with this type of questionnaire.

Response rate was an issue with the current study. Based on recommendations from previous research, a web-based survey was used. However, it is theorized that the low response rate may be attributed to the fact that the web-based system required the leader to create an online account in order to complete the questionnaire. This may have deterred some participants from responding. Future research should allow for multiple options for responding, which may increase the response rate. Additionally, some PDs may not be confident in their own leadership abilities and consequently chose not participate. Another reason for the low response rate may center on the fact that the field of research is limited and fairly new to the profession of Athletic Training. Only a small percentage of Athletic Trainers are actively involved in research. Some Athletic Training PDs may not understand the importance of participating in research and therefore may not complete research studies that are sent to them. Time demands may also have played a role in the low response rate. As described, PDs have many responsibilities and responding to surveys may be a low priority. A suggestion for obtaining a better response rate in the future is to tie the survey to a professional development activity, such as a 
workshop at a professional conference or as part of a leadership training program designed for Athletic Trainers.

\section{Conclusions}

Findings from this study indicated that changes to the current requirements for the role of PD may be warranted. With the rapid increase in the number of PDs and the always evolving academic environment, the Athletic Training PD must be well prepared for the position. Some PDs apply for the position lacking formal preparation (Passauer, 2004). This lack of preparation may lead to the PD becoming overwhelmed and possibly burnt out (Perkins \& Judd, 2001). Consideration should be given to increasing the minimum degree requirement and requiring leadership training. Future research may be useful in determining specific degree guidelines and types and amounts of leadership training that would be beneficial to Athletic Training PDs.

When asked to describe challenges of being an effective PD, responses included: lack of professional preparation, accreditation, administrative duties, and changing educational standards. Additionally, PDs should have measurable standards by which to assess their level of preparedness to assume the role of PD (Leone, 2008). A terminal degree was viewed as a practical strategy to impact university administration when advocating for the program. A doctoral degree commands a level of recognition and respect within academic units and departments (Leone, 2008). Many PDs have had to learn on the job versus receiving formal training in higher education, administration, and/or leadership (Leone, 2008). Transformational leadership can be learned over time and leadership training is a viable means to change a leader's behaviors in the expected 
direction. Changing leadership styles is possible and likely to result in changes to follower's perception, attitudes, and performance (Barling, Kelloway, \& Weber, 1996). 


\section{References}

Archie, C.B. (1997). Nursing department heads' transformational and transactional leadership: Relationships to nursing faculty satisfaction, willingness to exert extra effort, and perceived department head effectiveness. Dissertation Abstracts International, 58, no. 06A.

Avolio, B.J. \& Bass, B.M. (2004).Multifactor Leadership Questionnaire Sampler Set. Palo Alto, CA: Mind Garden.

Barling, J., Kelloway, E.K., \& Weber, T. (1996). Effects of transformational leadership training on attitudinal and financial outcomes: A field experiment. Journal of Applied Psychology. 81, 827-832.

Bass, B.M. (1985a). Leadership and performance beyond expectations. New York, NY: Free Press.

Bass, B.M. (1985b). Leadership: Good, better, best. Organizational Dynamics.13, 26-41.

Birnbaum, R. (1991).Faculty in governance: the role of senates and joint committees in academic decision-making. San Francisco, CA: Jossey-Bass.

Bordage, G., Foley, R., \&Goldyn, S. (2000) Skills and attributes of directors of Educational programs. Medical Education.34, 106-210.

Burns, J.M. (1978). Leadership. New York, NY: Harper Colophon.

Clos, K.L. (1997). Texas community college board chairs: An analysis of transformational leader behavior (trustees). Dissertation Abstracts International, 59-91A: 0066.

Commission on Accreditation in Physical Therapy Education. The Accreditation Handbook page. (2006). Retrieved from http://www.apta.org/AM/Template.cfm?Section=CAPTE1\&TEMPLATE=/CM/C ontentDisplay.cfm\&CONTENTID $=35141$

Commission on Accreditation of Athletic Training Education. The Accreditation Standards page. (2006). Retrieved from http://caate.net/ss_docs/standards.6.8.2006.pdf

Commission on Accreditation of Athletic Training Education Newsletter. (2007, Spring). Retrieved from http://caate.net 
Commission on Collegiate Nursing Education. The Standards for Accreditation of Baccalaureate and Graduate Nursing Programs.(2007). Retrieved from http://www.aacn.nche.edu/Accreditation/PDF/Procedures.pdf

Delforge, G.D., \&Behnke, R.S. (1999). The history and evolution of athletic training education in the united states. Journal of Athletic Training.34(1): 53-61.

Dunham, J., \&Klaffen, K.A. (1990). Transformational leadership and the nurse executive. Journal of Nursing Administration.20(4), 28-34.

Eagly, A. H., Johannesen-Schmidt, M. C., \& van Engen, M. L. (2003). Transformational, transactional, and laissez-faire leadership styles: A meta-analysis comparing women and Men. Psychological Bulletin.129 (4), 569-591.

Fisher, J.L. (1994). Reflections of transformational leadership. Educational Record. $75(3), 54,60-65$.

Footit, P.C. (2000). Transformational leadership practices of physical education chairpersons in higher education. Dissertation Abstracts International, 61, no. $09 A$.

Fredricks, S. M. (1998, Spring). Exposing and Exploring State-wide Community Leadership Training Programs. Journal of Leadership Studies, 129.

Hertel, J., West, T., Buckley, W., \&Denegar, C. (2001). Educational history, employment characteristics, and desired competencies of doctoral-educated athletic trainers. Journal of Athletic Training. 36(1), 49-57.

Hinkle, D.E., Wiersma, W., \&Jurs, S.G. (2003).Applied statistics for the behavioral sciences. Boston, MA: Houghton Mifflin.

Hoy, W.K., \&Miskel, C.G. (1996). Educational administration: Theory, research and practice. $5^{\text {th }} E d$. New York, NY: McGraw-Hill.

Judd, M.R. \& Perkins, S.A. (2004). Athletic training education program directors' perceptions on job selection, satisfaction, and attrition. Journal of Athletic Training.39(2), 185-192.

King, K.C. (1994). Transformational leadership in school of nursing deans: Perceived effectiveness, faculty satisfaction, and faculty willingness to put forth extra effort. Dissertation Abstracts International.

Kouzes, J.M. \& Posner, B.Z. The Leadership practices inventory: theory and evidence behind the five practices of exemplary leaders. Available at: http://www.theleaderhsipchallenge.com. Accessed July 18, 2007. 
Kuchinke, K.P. (1999). Workforce education faculty as leaders: Do graduate-level university instructors exhibit transformational leadership behaviors? Journal of Vocational Education Research, 24, 209-225.

Laurent, T.G., \&Bradney, D. A. (2007). Leadership behaviors of athletic training leaders compared with leaders in other fields. Journal of Athletic Training.42(1), 120125.

Leard, J.S., Booth, C.S., \& Johnson, J.C. (1991) A study of career pathways of NATA curriculum program directors. Journal of Athletic Training.26, 211-214.

Leone, J.E., Judd, M.R., \&Colandreo, R.M. (2008) Descriptive qualities of athletic training education program directors. Athletic Training Education Journal.2, 43 49.

Levine, M.F. (2000). The importance of leadership: An investigation of presidential style at fifty national universities. Dissertation Abstracts International, 61 no. $10 \mathrm{~A}$.

Mangus, B. (1998). The evolving roles of athletic training educators and clinicians. Journal of Athletic Training.22, 308-309.

McGuire, E. \&Kennerly, S.M. (2006). Nurse Managers as Transformational and Transactional Leaders. Nursing Economics. 24, 179-185.

National Athletic Trainers' Association. Available at: http://nata.org. Accessed December $1,2006$.

National Athletic Trainers' Association Education Council. Available at: http://nataec.org. Accessed February 12, 2007.

National Athletic Trainers' Association Education Task Force. (1997) Recommendations to reform athletic training education. NATA News. 2, 16-24.

Newman, I., \& Newman, C. (1994).Conceptual statistics for beginners. University Press of America.

Northouse, P.G. (2010). Leadership: Theory and practice. Thousand Oaks, CA: Sage

Nowicki, C.R. (1996). 21predictions for the future of hospital staff development. The Journal of Continuing Education in Nursing.27, 259-266.

Passauer, B.M. (2004).Administrative preparation of undergraduate athletic training program directors (dissertation). University of Pittsburgh. 
Perkins, S.A., \& Judd, M.R. (2001) Dilemmas of program directors: Then and now. Journal of Athletic Training.36, 396-400.

Peer, K.S., \&Rakich, J. S. (2000). Accreditation and continuous quality improvement in athletic training education. Journal of Athletic Training.35(2), 188-193.

Rankin, J.M., \& Ingersoll, C. (1995).Athletic training management: concepts and applications. St. Louis, MO: Mosby.

Ray, R. (2000) Management strategies in athletic training. $2^{\text {nd }}$ Ed. Champaign, IL: Human Kinetics.

Shaw, K.A. (1993). Sunflower seeds at Syracuse: cleaning up with TQM. Educational Record.74, 20-27.

Short, J.D. (1997). Profile of administrators of schools of nursing, part I: resources for goal achievement. Journal of Professional Nursing. 13(1), 7-12.

Starkey, C., \& Ingersoll, C.D. (2001). Scholarly productivity of athletic training faculty members. Journal of Athletic Training.36(2), 156-159.

Tourangeau, A. E. \&McGilton, K. (2004). Measuring leadership practices of nurses using the Leadership Practices Inventory. Nursing Research.53,182-189.

Yukl, G. A. (1989). Leadership in organizations. $4^{\text {th }}$ Ed. Upper Saddle River, NJ: Prentice Hall.

Zuest, G.M. (2003). Transformational and transactional leadership by athletic training education program directors. Dissertation Abstracts International.(UMI No. $3117391)$ 
APPENDICES

APPENDIX A

Demographic Questionnaire

\section{An Investigation of the Relationships between Selected Characteristics and Leadership Outcomes of Athletic Training Education Program Directors}

\section{Demographic Information}

Age _ Gender_

Number of years certified as an Athletic Trainer

Number of years as the Program Director at your current institution

Number of years as a Program Director overall

\section{Academic History}

Bachelor Degree

Field of Study

If other, please specify

Master Degree

Field of Study

If other, please specify

Doctorate Degree

Field of Study

If other, please specify

\section{Accreditation Experience}

Total number of years you have actively participated in Athletic Training accreditation related activities

Please indicate the number of years you have actively participated in Athletic Training accreditation related activities in the following roles:

Program Director

Clinical Coordinator

Faculty Member 
Approved Clinical Instructor/Clinical Instructor

Graduate Assistant

Doctoral Assistant

Other, please specify

\section{Leadership Training History}

Have you completed any academic coursework on leadership?

If yes, how many credit hours?

Have you completed any continuing education or additional activities pertaining to leadership?

If yes, please indicate the number of hours completed for each activity:

Number of Hours

Conference

Workshop

Lecture

Online Course

Home Study Course

Other, please specify

Thank you for completing this demographic questionnaire. Please submit the form via email to odaim@fiu.edu. You may also submit via fax with a cover letter to 305-348-2125. If you have any questions, please contact Michelle Odai at 305-348-6335 or odaim@fiu.edu. 
VITA

\section{MICHELLE L. ODAI}

April 22, 1977

Born, Syracuse, New York

EDUCATION

2001

M.S., Athletic Training

California University of Pennsylvania

California, Pennsylvania

1999

B.S., Exercise Science

University of Rhode Island

Kingston, Rhode Island

PROFESSIONAL EXPERIENCE

2007 - Present

2005-2007

$2001-2005$
Clinical Assistant Professor

Florida International University

Miami, Florida

Doctoral Assistant

Florida International University

Miami, Florida

Assistant Professor

Alderson-Broaddus College

Philippi, West Virginia 